Article

\title{
A Transportable Photovoltaic Power Generation System Utilizing a SiC Inverter and Spherical Si Solar Cells
}

\author{
Yuji Ando ${ }^{1}$, Takeo Oku ${ }^{1, *}$, Masashi Yasuda ${ }^{2}$, Kazufumi Ushijima ${ }^{3}$ and Mikio Murozono ${ }^{4}$ \\ 1 Department of Materials Science, The University of Shiga Prefecture, 2500 Hassaka, Hikone, Shiga 522-8533, \\ Japan; ando.y@mat.usp.ac.jp \\ 2 Collaborative Research Center, The University of Shiga Prefecture, 2500 Hassaka, Hikone, Shiga 522-8533, \\ Japan; yasuda.m@office.usp.ac.jp \\ 3 ArumoTech Corporation, 572 Sanboh-Nishinotohincho, Nakagyou-ku, Kyoto 604-8277, Japan; \\ u.design@nifty.com \\ 4 Clean Venture 21 Co., 38 Ishihara Douno-Ushirocho, Kissyouin, Minami-ku, Kyoto 601-8355, Japan; \\ murozono@cv21.co.jp \\ * Correspondence: oku@mat.usp.ac.jp; Tel.: +81-749-28-8368
}

Academic Editor: Manoj Gupta

Received: 10 March 2017; Accepted: 19 April 2017; Published: 21 April 2017

\begin{abstract}
This paper reports a 100-W class transportable photovoltaic (PV) power generation system built with $\mathrm{SiC}$ power devices. Conventionally, studies on $\mathrm{SiC}$ power converters have mostly focused on multi-kW applications. In this paper, we have verified the feasibility of the $\mathrm{SiC}$ power devices for sub-kW PV power generation systems. The developed PV power generation system consisted of a spherical Si solar cell module, a 150-W SiC PV-inverter unit with maximum power point tracking (MPPT) function, and a $12-\mathrm{V}$ Li-ion battery. The total weight of the system was just $4.3 \mathrm{~kg}$. Conversion efficiencies of the MPPT charge controller and the direct current-alternating current converter reached $98.0 \%$ and $88.4 \%$, respectively. The developed system exhibited stable output power characteristics, even when the weather conditions were fluctuated. These compactness, high efficiencies, and excellent stability clearly indicated the feasibility of $\mathrm{SiC}$ power devices even for sub-kW class PV power generation systems. This kind of system would be available for the applications where compactness and transportability are of tremendous importance.
\end{abstract}

Keywords: silicon carbide; spherical Si solar cell; photovoltaic inverter; maximum power point tracking; DC-AC converter; lithium-ion battery

\section{Introduction}

In the modern power electronics, the electron device requirements include a high blocking voltage, a low $\mathrm{ON}$ resistance, a high switching frequency, and good reliability. These requirements have led to a great interest in power devices based on wide gap semiconductors such as $\mathrm{GaN}$ and $\mathrm{SiC}$ [1-3]. The main advantage of wide gap semiconductors is their very high electric field capability. Wide gap semiconductors possess high critical field strengths. This means that a thinner epi layer is required to block the same voltage compared with Si devices. Thus, switching devices with much lower ON resistances can be fabricated using $\mathrm{GaN}$ or $\mathrm{SiC}$. A lower $\mathrm{ON}$ resistance improves the efficiency of inverters due to reduced conduction and switching losses, and also decreases the module size due to the increased power density. The high electron mobility of GaN allows switching operations with higher frequencies, which also decreases the module size because of the smaller passive components. The excellent thermal stability of $\mathrm{SiC}$ and $\mathrm{GaN}$ should enable devices based on these materials to operate at high temperatures. 
Since the first photovoltaic (PV) inverter using SiC diodes by Phlippen and Burger [4] and that using $\mathrm{SiC}$ transistors by Stalter et al. [5], there have been considerable reports on the applications of $\mathrm{SiC}$ devices on power converters [6-8]. Concerning direct current (DC)-DC converters, interleaved boost converters built with $\mathrm{SiC}$ bipolar junction transistors (BJTs) and SiC Schottky barrier diodes (SBDs) were presented in [9] and [10], respectively. Ref. [10] reported a converter with a rated power of $2500 \mathrm{~W}$ built with 900-V advanced Si metal-oxide-semiconductor field-effect transistors (MOSFETs) and $1200-\mathrm{V}$ SiC SBDs. In [9], the employment of 1200-V SiC BJTs realized a 5500-W converter. Concerning DC-alternating current (AC) converters, single-phase inverters using SiC junction field-effect transistors (JFETs) and SiC MOSFETs were presented in [11] and [12], respectively. Ref. [11] reported a 2500-W single-phase inverter built with $1200-\mathrm{V}$ SiC JFETs. In [12], the employment of 1200-V SiC MOSFETs realized a 5000-W single-phase inverter. Three-phase inverters using SiC JFETs and SiC MOSFETs were reported in [13] and [14], respectively. Ref. [14] reported a 7000-W three-phase inverter built with $1200-\mathrm{V}$ SiC MOSFETs. In [13], the employment of 1200-V SiC JFETs realized a 5000-W three-phase inverter with a high switching frequency of $144 \mathrm{kHz}$. Recently, $[15,16]$ reported all SiC inverters. Some authors [17-19] also gave a comparative study of Si- and SiC-based power converters. Ref. [20] gave a comprehensive review on SiC-based PV-inverters. As mentioned above, several device structures were adopted as SiC-based active switches such as MOSFET, JFET, and BJT. The SiC MOSFET, the first $\mathrm{SiC}$-based transistor to be commercially available, is a voltage-controlled normally-off device, which makes this device user-friendly. The SiC BJT and the SiC JFET are rather immature devices. However, these devices are expected to have the advantage of a low ON resistance, since they are free from the mobility degradation due to interface traps that is significant in the MOSFET. The SiC BJT is a normally-off device but being current-controlled, which requires a special driver circuit. The SiC JFET have a p-n junction at the gate, which conducts with a positive voltage swing corresponding to the bandgap (approximately $3 \mathrm{~V}$ ). In the case of the normally-off JFET, it requires a significantly large gate voltage to turn on the device completely. Therefore, it also requires a special driver circuit.

In the literature, studies on power converters using $\mathrm{SiC}$ devices mostly focused on multi-kW class applications. The reason is that advantages of a lower $\mathrm{ON}$ resistance of $\mathrm{SiC}$ devices were considered lost in sub-kW class power converters. In addition, most of developed power converters were examined as a stand-alone equipment. Concerning PV applications, however, performances of the total system including PV-inverters and solar cells should also be investigated. Recently, we reported 300-W class power converters using $\mathrm{SiC}$ devices [21-23]. This kind of inverter would be available for the applications where compactness and transportability are of tremendous importance, such as mobile computing systems, security monitoring or sensing systems, auxiliary power supply systems for automobiles or drones, emergency power supply systems. More recently, we have developed a 150-W $\mathrm{PV}$-inverter using $\mathrm{SiC}$ power devices [24,25]. An increase in the switching frequency of the inverter achieved a state-of-the-art combination of weight $(1.3 \mathrm{~kg})$ and size $(250 \mathrm{~mm} \times 180 \mathrm{~mm} \times 28 \mathrm{~mm})$ as this class inverter. Besides being compact, it exhibited an approximately $3 \%$ higher conversion efficiency as compared to commercial Si-based inverters.

The aim of this paper is to verify the feasibility of $\mathrm{SiC}$ power devices for sub-kW applications. For this purpose, we have constructed and characterized a 150-W transportable PV power generation system using the developed $\mathrm{SiC}$ inverter. The present system consisted of the SiC-based inverter unit, a spherical Si solar cell module, and a Li-ion battery. The spherical Si cell module [26] that is lightweight, flexible, and economical is suitable for transportable PV applications. To study the electrical power stability in the actual use condition, we have carried out the continuous operation measurements of the developed system including the solar cell module, the PV-inverter, and the storage battery. In addition, the battery duration time without the aid of the solar cell module was measured and compared with calculations. 


\section{Materials and Methods}

Figure $1 \mathrm{a}, \mathrm{b}$ is photographs of the developed PV power generation system taken from the top and bottom, respectively. A PV-inverter unit and a Li-ion battery were attached on the bottom side of a solar cell module. Figure 1c illustrates setup of this system. The PV-inverter unit contained a DC-AC converter and a maximum power point tracking (MPPT) charge controller. The MPPT controller was driven by the input voltage regulation [27]. The inverter circuit consisted of a front stage DC-DC converter followed by a second stage DC-AC converter. The DC-DC part was a push-pull converter built with four SiC SBDs (SCS210AJ, ROHM Semiconductor, Kyoto, Japan) [28]. The DC-AC part was a single-phase full-bridge inverter built with four SiC MOSFETs (SCT2120AF, ROHM Semiconductor, Kyoto, Japan) [29]. The rated output power was $150 \mathrm{~W}$. Basically, the switching frequency of the pulse width modulation was determined to balance the compactness and the efficiency of the circuit. In addition, we took care of the charging time of the bootstrap circuit used in the gate drive of the high-side transistors. In the DC-AC part, the switching frequency was set to $100 \mathrm{kHz}$ to insure sufficient time to charge the bootstrap capacitors. On the other hand, in the DC-DC part, the switching frequency was set to $200 \mathrm{kHz}$, since it included no bootstrap circuit. As the power source, a spherical Si solar cell module (CVFM-0540T2-WH, Clean Venture 21, Kyoto, Japan) was used. The maximum power point current and voltage were $3.34 \mathrm{~A}$ and $16.2 \mathrm{~V}$, respectively. The rated output power was $54 \mathrm{~W}$. The MPPT circuit not only controlled the load of the cell to maximize the PV output power, but also stabilized the electric power supplied to the DC-AC converter by charging and discharging Li-ion battery (Lifepo4, O'Cell Technology, Shenzhen, China). The rated voltage and capacity of the battery were $12 \mathrm{~V}$ and 3.3 Ah, respectively. Table 1 summarizes size and weight of the individual units and total system. To the best of our knowledge, the developed SiC inverter achieved a state-of-the-art combination of the weight $(1.3 \mathrm{~kg})$ and the volume $\left(1260 \mathrm{~cm}^{3}\right)$ for $150-250 \mathrm{~W}$ class inverters [30]. Weight of the total system including power cables and AC outlets was $4.3 \mathrm{~kg}$.

Table 1. Size and weight of the individual units and total system.

\begin{tabular}{ccc}
\hline Unit & Size $\left(\mathbf{m m}^{3}\right)$ & Weight $\mathbf{~ k g )}$ \\
\hline Inverter & $250 \times 180 \times 28$ & 1.3 \\
Solar cell & $1020 \times 690 \times 5$ & 2.2 \\
Battery & $110 \times 66 \times 28$ & 0.4 \\
Total system & --- & $4.3^{*}$ \\
\hline
\end{tabular}

* The total system includes power cables and AC outlets.

(a)

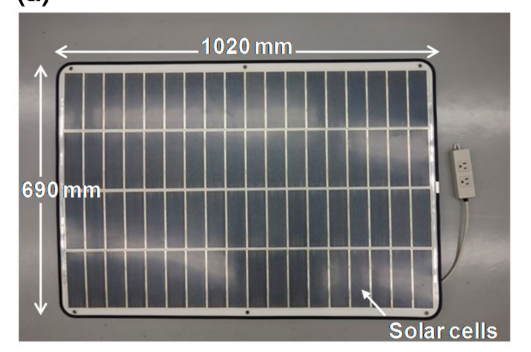

(b)

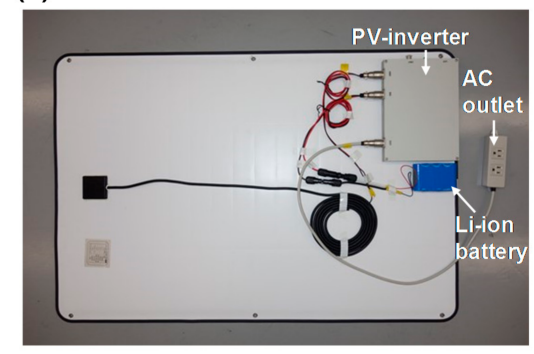

(c)

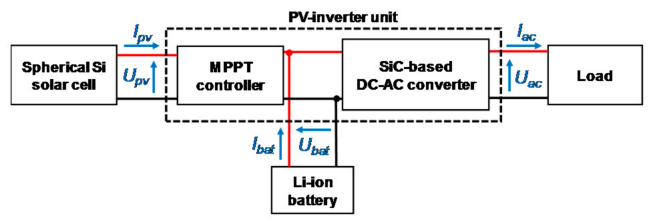

Figure 1. Photographs from (a) the top and (b) the bottom of the developed photovoltaic (PV) power generation system and (c) its block diagram. 


\section{Results}

\subsection{Conversion Efficiencies of the SiC Inverter}

First, we have characterized conversion efficiencies of the individual circuits of the developed SiC inverter, separately. The conversion efficiency of the MPPT controller was measured by connecting an alternative power supply to the solar cell terminal of the inverter, while making the inverter circuit inactive. Losses of power cables were corrected by directly measuring their resistances. Resistance of the power cable was $89 \mathrm{~m} \Omega$ between the solar cell terminal of the inverter and the power meter. This value was $20 \mathrm{~m} \Omega$ between the battery terminal and the power meter. The loss of the cable between the $\mathrm{AC}$ terminal and the power meter was neglected since the current value was small. Figure 2a presents corrected and uncorrected MPPT efficiency with respect to DC input power. The corrected MPPT efficiency exceeded $97 \%$ when DC input power was over $24 \mathrm{~W}$, and the peak efficiency reached $98.0 \%$.

(a)

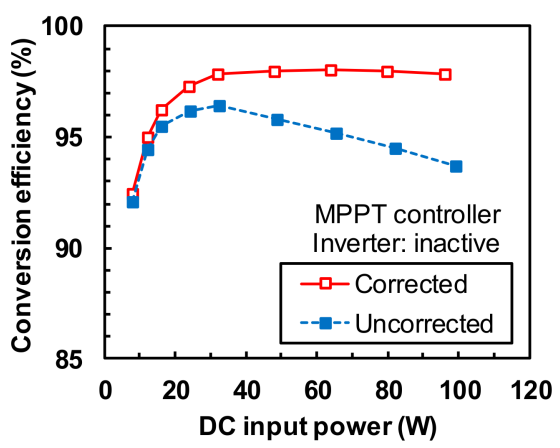

(b)

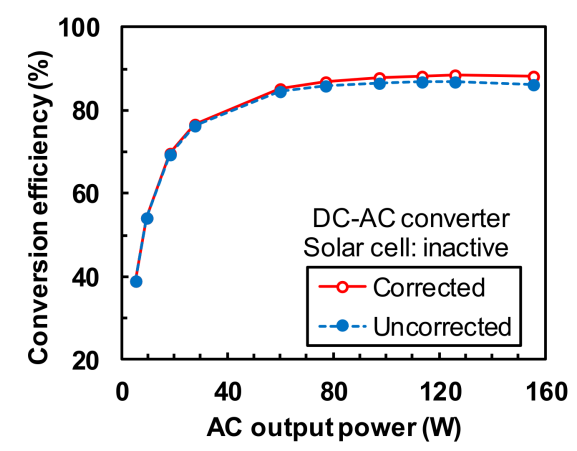

Figure 2. (a) Conversion efficiency of the maximum power point tracking (MPPT) controller vs. DC power and (b) conversion efficiency of the DC-AC converter vs. AC power. Results with (solid) and without (dotted) the correction of cable losses are shown.

The conversion efficiency of the DC-AC converter was measured by changing the load power, while making the solar cell module inactive. Figure $2 b$ presents corrected and uncorrected efficiencies with respect to AC output power. Corrected DC-AC conversion efficiency exceeded $85 \%$ when the output power was over $60 \mathrm{~W}$, and the peak efficiency reached 88.4\%. A commercial Si-based 300-W DC-AC converter (SXCD-300, Daiji Industry, Kashiwara, Japan) was also measured with the same equipment. The obtained conversion efficiency was approximately $3 \%$ higher in the SiC inverter than in the Si inverter [24,25]. In sub-kW class inverters, the ON resistance was considered to have little influence on the efficiency. The loss analysis [30,31] indicated this improvement was due to decreased DC-DC conversion loss and suppressed switching losses in SiC devices.

\subsection{Electric Power Stability: Measurement Started from a Discharged Condition}

To investigate the electric power stability of this PV system, continuous operation measurements were performed with the solar cell active. Concerning the battery condition, we have tested two typical cases, those were, an exhausted condition and a fully charged condition. First, the measurement was carried out using an almost exhausted battery in the initial condition. The load power was set at $10 \mathrm{~W}$. Figure 3a-c show variations in the voltage, current, and power values, respectively. In these figures, subscripts $p v, b a t$, and $a c$ to the voltage $U$, current $I$, and power $P$ mean the solar cell, battery, and AC terminals of the inverter, respectively (see Figure 1c). In Figure 3d, variations in the conversion efficiencies of the MPPT controller, inverter, and total system are shown. Here, the total efficiency $\left(\eta_{\text {tot }}\right)$ of the inverter was introduced by [24].

$$
\eta_{t o t}=\frac{P_{a c}}{P_{p v}+P_{b a t}}
$$


Figure $4 \mathrm{a}, \mathrm{b}$ show corresponding variations in solar radiation power and those of temperature and humidity, respectively. The weather was cloudy.

Before 12:30 (the period I in Figures 3 and 4), the output current of the battery $\left(I_{\text {bat }}\right)$ ranged between -2 and $0 \mathrm{~A}$, while that of the solar cell $\left(I_{p v}\right)$ ranged between 1 and $3 \mathrm{~A}$. In this period, the electric power provided by the solar cell $\left(P_{p v}\right)$ was not only supplied to the load, but also used to charge the storage battery. From 12:30 to 14:30 (the period II), $I_{b a t}$ was almost zero, while $I_{p v}$ was close to $1.1 \mathrm{~A}$. In this period, the storage battery was fully charged, and the whole of $P_{p v}$ was supplied to the load. After 14:30 (the period III), $I_{b a t}$ was increased from 0 to $1.3 \mathrm{~A}$, while $I_{p v}$ was decreased from 1.1 to $0 \mathrm{~A}$. In this period, the solar radiation power $\left(P_{\text {solar }}\right)$ fell below $0.3 \mathrm{~kW} \cdot \mathrm{m}^{-2}$, as shown in Figure $4 \mathrm{a}$. The storage battery was discharging the electric power to compensate the decrease in $P_{p v}$. Throughout a whole measurement, considerable variations were observed in the solar radiation power, the temperature, and the humidity, as shown in Figure 4a,b. As a result, violent fluctuations were observed in the voltage $\left(U_{p v}, U_{b a t}\right)$, current $\left(I_{p v}, I_{b a t}\right)$, and power $\left(P_{p v}, P_{b a t}\right)$ both at the solar cell and battery terminals. Concerning the AC output electricity, however, the voltage $\left(U_{a c}\right)$, current $\left(I_{a c}\right)$, and power $\left(P_{a c}\right)$ were very stable. In this measurement, the total efficiency ranged between 47 and $55 \%$. This low efficiency value was attributed to the low output power of $10 \mathrm{~W}$. In such a condition, the efficiency was predominantly determined by non-load losses due to transformers in DC-DC converter circuit, electrolytic capacitors of the filter circuit, and so on.

Correlation between the electric power and $P_{\text {solar }}$ was analyzed based on these results. Figure 5a shows correlation between $P_{p v}$ and $P_{\text {solar }}$, while Figure $5 \mathrm{~b}$ shows correlation between $P_{b a t}$ and $P_{\text {solar }}$. Straight line fits show groups of data I, II, and III, which correspond to periods I (charging condition), II (fully charged condition), and III (discharging condition), respectively in Figures 3 and 4 . In the group II, $P_{p v}$ was almost constant independently of variation of $P_{\text {solar }}$. This is because the battery was fully charged, and hence, $P_{p v}$ was limited below sum of the load power $(10 \mathrm{~W})$ and the accompanying loss. The boundary between the group III and the other groups was located approximately at $0.3 \mathrm{~kW} \cdot \mathrm{m}^{-2}$. This indicated that the $10-\mathrm{W}$ load system continuously operated without discharging the storage battery as long as $P_{\text {solar }}$ exceeded $0.3 \mathrm{~kW} \cdot \mathrm{m}^{-2}$.
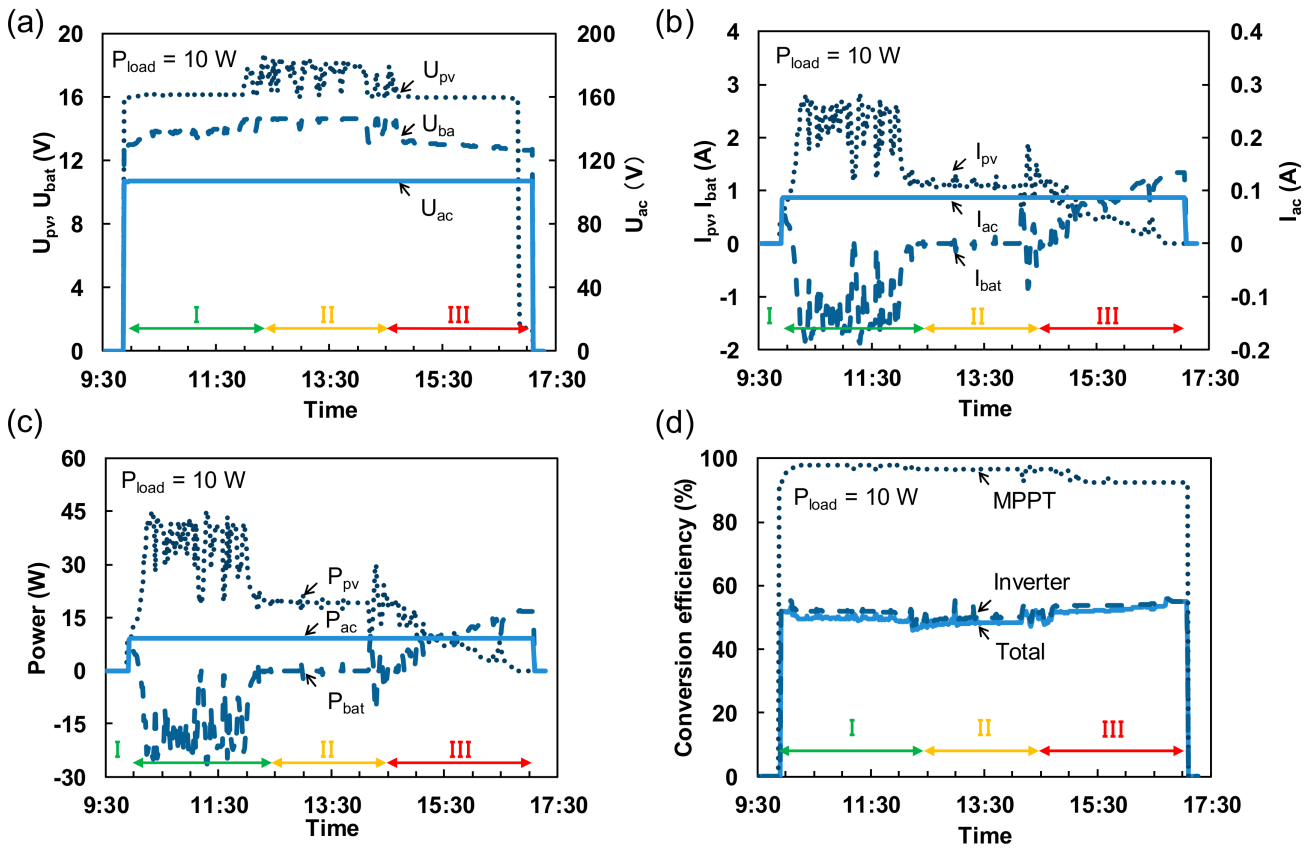

Figure 3. Variation in (a) voltage, (b) current, and (c) power at PV, battery, and AC terminals and (d) conversion efficiencies of MPPT controller, DC-AC converter, and total circuits. In the beginning of the measurement, the storage battery was almost exhausted. The load power was $10 \mathrm{~W}$. 
(a)

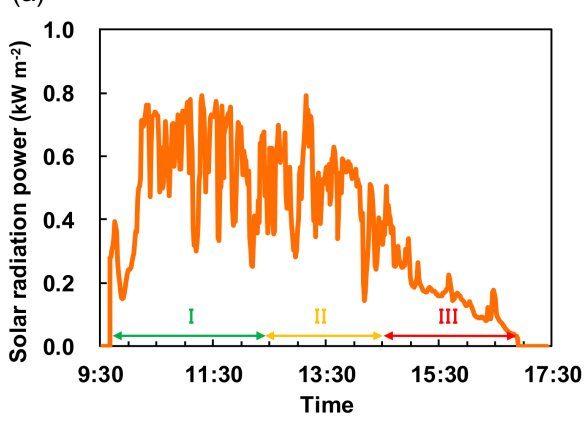

(b)

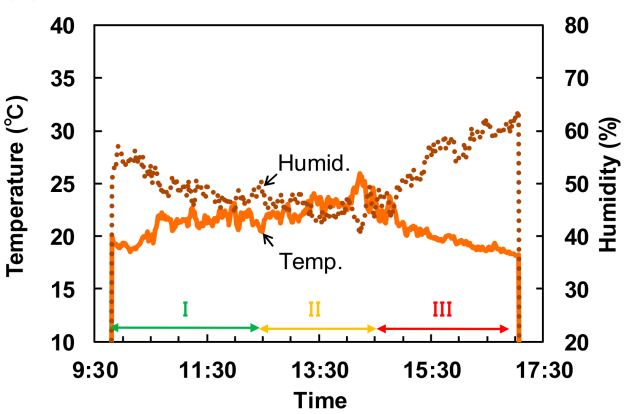

Figure 4. Variation in (a) the solar radiation power and (b) the temperature and humidity during the measurements shown in Figure 3.

(a)

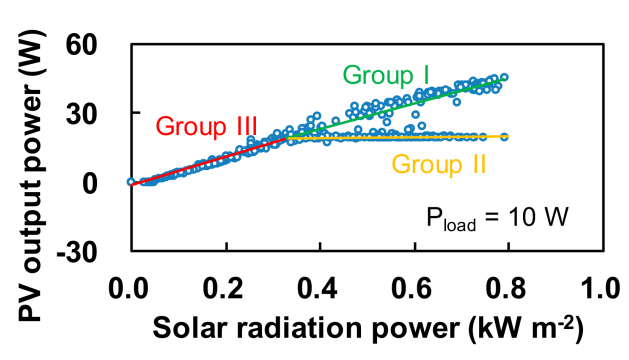

(b)

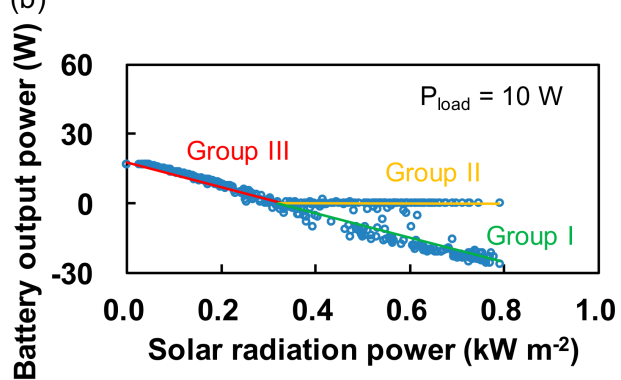

Figure 5. (a) Correlation between the PV output power and the solar radiation power and (b) that between the battery output power and the solar radiation power. These data were collected from the measured data in Figures 3 and 4.

\subsection{Electric Power Stability: Measurement Started from a Fully Charged Condition}

Next, we have carried out the measurement using a fully charged battery in the initial condition. The load power was set at $30 \mathrm{~W}$. Figure $6 \mathrm{a}-\mathrm{c}$ show variations in the voltage, current, and power values, respectively. In Figure 6d, variations in the conversion efficiencies of the MPPT controller, inverter, and total system are shown. Figure $7 \mathrm{a}, \mathrm{b}$ show corresponding variations in solar radiation power and those of temperature and humidity, respectively. The weather was clear.

Before 13:30 (the period II in Figures 6 and 7), $I_{b a t}$ was almost zero, while $I_{p v}$ was close to $2.3 \mathrm{~A}$. In this period, the storage battery was in a fully charged condition, and the whole of $P_{p v}$ was supplied to the load. After 13:30 (the period III), $I_{b a t}$ was increased from 0 to $2.3 \mathrm{~A}$, while $I_{p v}$ was decreased from 2.3 to 0 A. In this period, $P_{\text {solar }}$ fell below $0.5 \mathrm{~kW} \cdot \mathrm{m}^{-2}$, as shown in Figure $7 \mathrm{a}$. The storage battery was discharging the electric power to compensate the decrease in $P_{p v}$. In this case, the period I $\left(I_{b a t}<0\right)$ was seldom observed. From 13:30 to 14:30, considerable variations were observed in the solar radiation power, the temperature, and the humidity, as shown in Figure 7a,b. As a result, violent fluctuations were observed in the voltage, current, and power both at the solar cell and battery terminals. Concerning the AC output electricity, however, these variables were very stable. The total efficiency ranged between $72 \%$ and $76 \%$.

Correlation between the electric power and $P_{\text {solar }}$ was analyzed based on these results. Figure 8a shows correlation between $P_{p v}$ and $P_{\text {solar }}$, while Figure $8 \mathrm{~b}$ shows correlation between $P_{b a t}$ and $P_{\text {solar }}$. Straight line fits show groups of data II and III, which correspond to periods II (fully charged condition) and III (discharging condition), respectively in Figures 6 and 7. In contrast with Figure 5, group I disappeared in this case. In the group II, $P_{p v}$ was almost constant independently of variation of $P_{\text {solar }}$. This is because the battery was fully charged, and hence, $P_{p v}$ was limited below sum of the load power $(30 \mathrm{~W})$ and the accompanying loss. The boundary between the groups III and II was 
located approximately at $0.5 \mathrm{~kW} \cdot \mathrm{m}^{-2}$. This indicated that the $30-\mathrm{W}$ load system continuously operated without discharging the storage battery as long as $P_{\text {solar }}$ exceeded $0.5 \mathrm{~kW} \cdot \mathrm{m}^{-2}$.

(a)
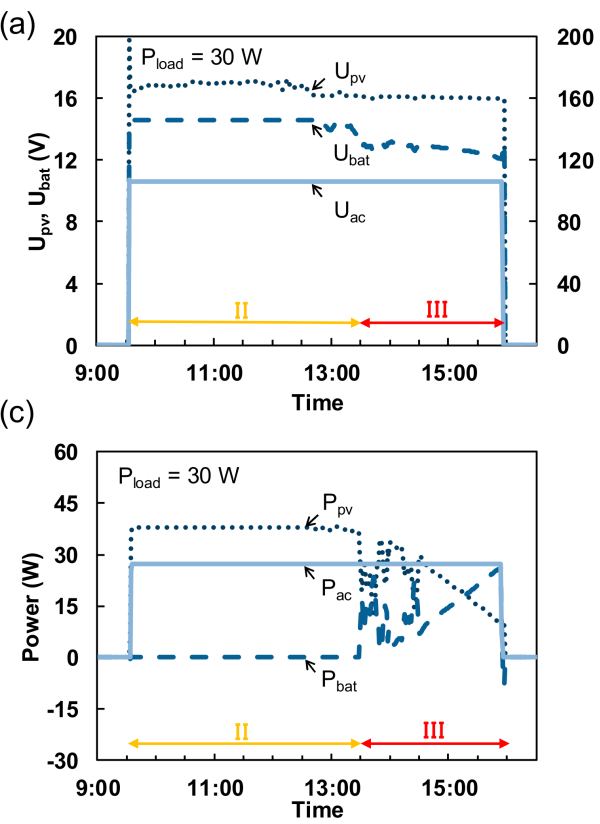

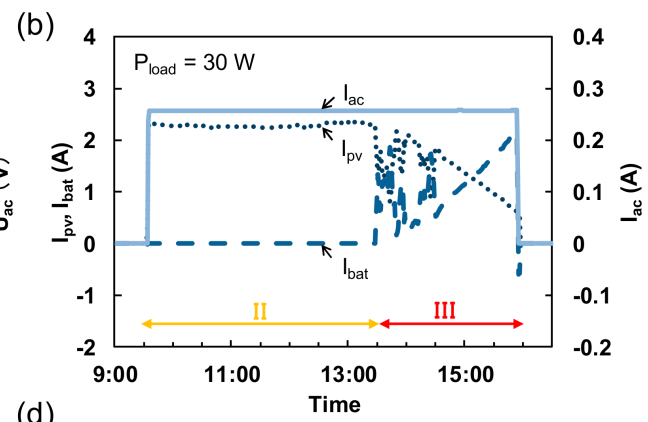

(d)

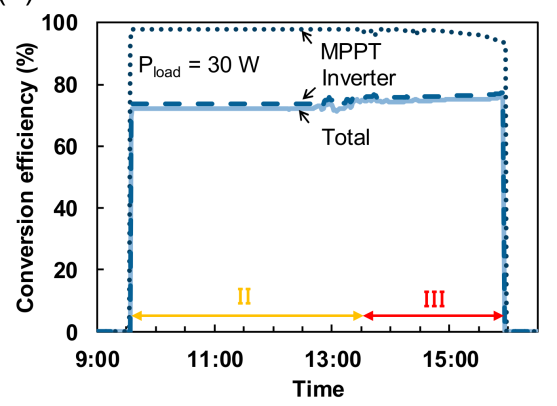

Figure 6. Variation in (a) voltage, (b) current, and (c) power at PV, battery, and AC terminals and (d) conversion efficiencies of MPPT controller, DC-AC converter, and total circuits. In the beginning of the measurement, the storage battery was fully charged. The load power was $30 \mathrm{~W}$.

(a)

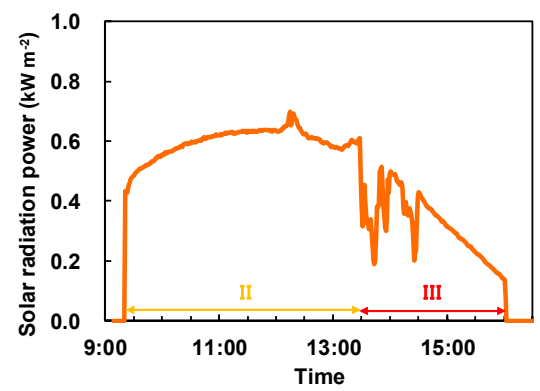

(b)

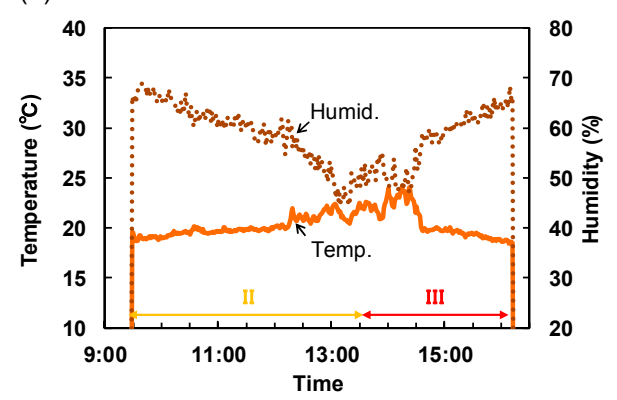

Figure 7. Variation in (a) the solar radiation power and (b) the temperature and humidity during the measurements shown in Figure 6.

(a)

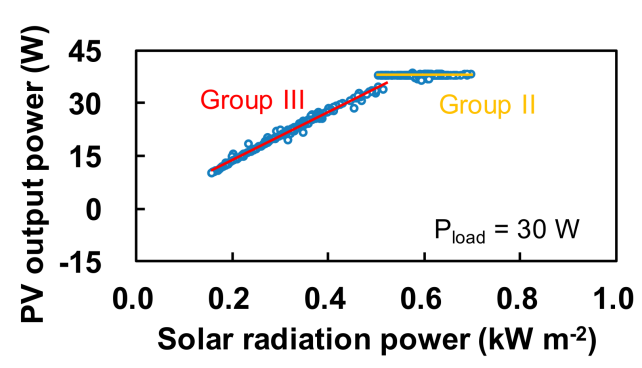

(b)

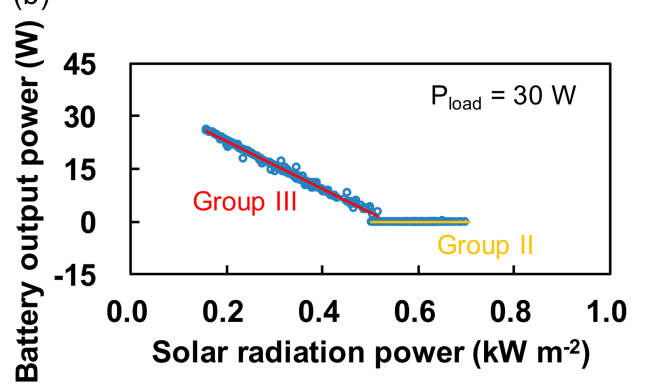

Figure 8. (a) Correlation between the PV output power and the solar radiation power and (b) that between the battery output power and the solar radiation power. These data were collected from the measured data in Figures 6 and 7. 


\subsection{Battery Duration Time}

To estimate the battery duration time $\left(t_{b a t}\right)$, we have performed continuous operation measurements with the solar cell inactive. Figure 9 shows variations in $U_{b a t}$ for different load power values. As the load was applied, $U_{b a t}$ dropped down from the open-circuit voltage, and then it was gradually decreased. As $U_{b a t}$ fell below $11.5 \mathrm{~V}$, the under-voltage-lockout function turned off the inverter and $U_{b a t}$ rose to the open-circuit voltage. The $t_{b a t}$ value was $2.4 \mathrm{~h}$ under a $10-\mathrm{W}$ load, while it was just $1 \mathrm{~h}$ under a 30-W load. The relatively short duration times were due to the small battery capacity of 3.3 Ah. An increase in the battery capacity should extend the duration time.

To estimate the effect of the battery capacity, we have simply calculated $t_{b a t}$ by

$$
t_{b a t}\left(P_{a c}, Q_{b a t}\right)=\frac{Q_{b a t} V_{b a t} \eta_{i n v}\left(P_{a c}\right)}{P_{a c}}
$$

In this expression, $Q_{b a t}$ is the battery capacity, $V_{b a t}$ is the battery voltage $(12 \mathrm{~V})$, and $\eta_{\text {inv }}\left(P_{a c}\right)$ is $P_{a c}$ dependence of the inverter efficiency that is shown in Figure $2 \mathrm{~b}$. Figure 10 plots calculated relationship between $t_{b a t}$ and $P_{a c}$, where $Q_{b a t}$ was ranged from 3.3 to $10 \mathrm{Ah}$. Also plotted are measured results obtained from Figure 9. Satisfactory agreement was obtained between the measurement and the calculation for $Q_{b a t}=3.3 \mathrm{Ah}$. By increasing $Q_{\text {bat }}$ up to $10 \mathrm{Ah}$, the $t_{b a t}$ values were estimated to be 7 and $3 \mathrm{~h}$ for 10-W and 30-W loads, respectively. In this case, the weight of the total system was estimated to be $5.1 \mathrm{~kg}$.

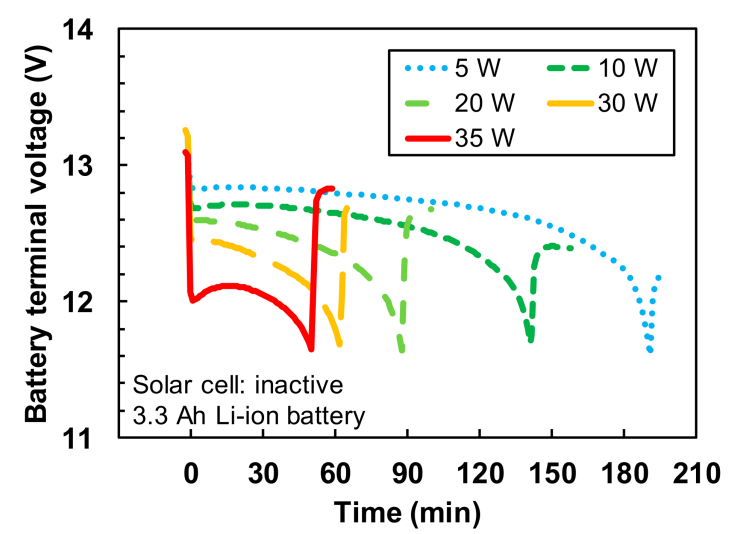

Figure 9. Variation in the voltage at the battery terminal measured for different load power values. In these measurements, the solar cell was inactive.

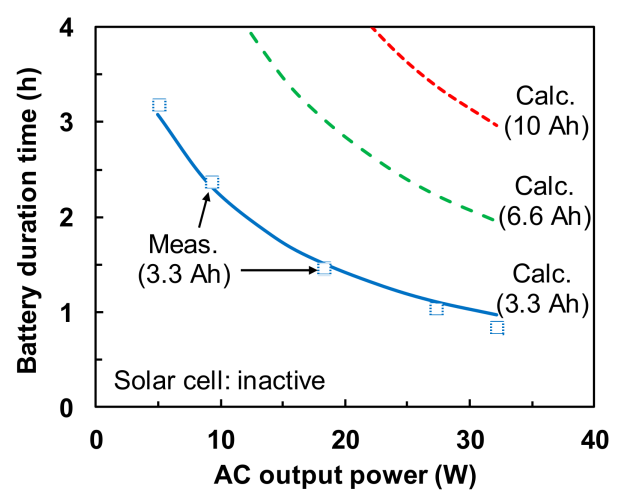

Figure 10. Calculated battery duration time versus the AC output power with the battery capacity ranging from 3.3 to $10 \mathrm{Ah}$ (Lines). Measured battery duration time with the battery capacity of $3.3 \mathrm{Ah}$ (squares). In these calculations and measurements, the solar cell was inactive. 


\section{Conclusions}

To verify the feasibility of SiC power devices for sub-kW applications, we have constructed a transportable 150-W PV power generation system using the SiC inverter. The developed PV power generation system consisted of a spherical Si solar cell module (rated power: $54 \mathrm{~W}$ ), a SiC-based PV-inverter unit with MPPT functions (rated power: $150 \mathrm{~W}$ ), and a $12 \mathrm{~V} \mathrm{Li}$-ion battery (battery capacity: 3.3 Ah). The developed $\mathrm{SiC}$ inverter achieved a state-of-the-art combination of the weight $(1.3 \mathrm{~kg})$ and the volume $\left(1260 \mathrm{~cm}^{3}\right)$ for $150-250 \mathrm{~W}$ class inverters. The total weight of the PV power generation system was just $4.3 \mathrm{~kg}$. The conversion efficiency of the DC-AC converter reached $88.4 \%$, which was approximately $3 \%$ higher than the commercial Si-based inverter. The conversion efficiency of the MPPT charge controller reached $98.0 \%$. Stabilities of the electric power and efficiency of this system were studied for two typical battery conditions; those were a fully charged condition and an almost exhausted condition. For both conditions, the system exhibited stable output power characteristics, even when the weather conditions were fluctuated. The battery duration time without the aid of the solar cell was estimated to be $3 \mathrm{~h}$ for a $30-\mathrm{W}$ load operation, when the battery capacity was increased to $10 \mathrm{Ah}$. These compactness, high efficiencies, and excellent stability clearly indicated the feasibility of SiC power devices even for sub-kW class PV power generation systems. This kind of system is available for the applications where compactness and transportability are of tremendous importance, such as mobile computing systems, security monitoring or sensing systems, auxiliary power supply systems for automobiles or drones, and emergency power supply systems.

Acknowledgments: This study was supported by the Super Cluster Program of the Japan Science and Technology Agency (JST).

Author Contributions: Yuji Ando performed the experiments and analyzed the data; Yuji Ando and Takeo Oku wrote the paper; Takeo Oku and Masashi Yasuda designed the photovoltaic system; Kazufumi Ushijima developed the inverter circuit; and Mikio Murozono developed the solar cell module. All authors have read and approved the final manuscript.

Conflicts of Interest: The authors declare no conflict of interest.

\section{References}

1. Labedev, A.A.; Chelnokov, V.E. Wide-gap semiconductors for high-power electronics. Semiconductors 1999, 33, 999-1001. [CrossRef]

2. Monroy, E.; Omnès, F.; Calle, F. Wide-bandgap semiconductor ultraviolet photodetectors. Semicond. Sci. Technol. 2003, 18, R33-R51. [CrossRef]

3. Okumura, H. Present status and future prospect of widegap semiconductor high-power devices. Jpn. J. Appl. Phys. 2006, 45, 7565-7586. [CrossRef]

4. Phlippen, F.; Burger, B. A new high voltage Schottky diode based on silicon-carbide (SiC). In Proceedings of the 9th European Conference Power Electronics and Applications (EPE 2001), Graz, Austria, 27-28 August 2001; p. 00259.

5. Stalter, O.; Burger, B.; Lehrmann, S. Silicon carbide (SiC) D-MOS for grid-feeding solar inverters. In Proceedings of the 12th European Conference Power Electronics and Applications (EPE 2007), Aalborg, Denmark, 2-5 September 2007; pp. 1-10.

6. Chinthavali, M.; Zhang, H.; Tolbert, L.M.; Ozpineci, B. Update on SiC-based inverter technology. In Proceedings of the 2009 Brazilian Power Electronics Conference (COBEP 2009), Bonito, Mato Grosso do Sul, Brazil, 27 September-1 October 2009; pp. 71-79.

7. Yamane, A.; Koyanagi, K.; Kozako, M.; Fuji, K.; Hikita, M. Fabrication and evaluation of SiC inverter using SiC-MOSFET. In Proceedings of the IEEE 10th International Conference Power Electronics and Drive Systems (PEDS 2013), Kitakyushu, Japan, 22-25 April 2013; pp. 1029-1032.

8. Li, L.; Li, C.; Cao, Y.; Wang, F. Recent progress of SiC power devices and applications. IEEJ Trans. Electr. Electron. Eng. 2013, 8, 515-521. [CrossRef] 
9. Hensel, A.; Wilhelm, C.; Kranzer, D. Development of a boost converter for PV systems based on SiC BJTs. In Proceedings of the 14th European Conference on Power Electronics and Applications (EPE 2011), Birmingham, UK, 30 August-1 September 2011; pp. 1-7.

10. Ho, C.N.M.; Breuninger, H.; Pettersson, S.; Escoba, G.; Coccia, A.; Oikonomous, N. Practical implementation of an interleaved boost converter using $\mathrm{SiC}$ diodes for PV applications. In Proceedings of IEEE 8th International Conference Power Electronics \& ECCE Asia (ICPE 2011-ECCE Asia), Jeju, Korea, 30 May-3 June 2011; pp. 372-379.

11. Kranzer, D.; Wilhelm, C.; Reiners, F.; Burger, B. Application of normally-off SiC-JFETs in photovoltaic inverters. In Proceedings of the 13th European Conference Power Electronics and Applications (EPE 2009), Barcelona, Spain, 8-10 September 2009; pp. 1-6.

12. Burger, B.; Kranzer, D.; Stalter, O. Cost reduction of PV-inverters with SiC-DMOSFETs. In Proceedings of the 2008 5th International Conference on Integrated Power Electronics Systems (CIPS 2008), Nuremberg, Germany, 11-13 March 2008; pp. 1-5.

13. Stalter, O.; Kranzer, D.; Rogalla, S.; Burger, B. Advanced solar power electronics. In Proceedings of the 22nd International Symposium Power Semiconductor Devices \& IC's (ISPSD 2010), Hiroshima, Japan, 6-10 June 2010; pp. 3-10.

14. Burger, B.; Kranzer, D.; Stalter, O. Efficiency improvement of PV inverters with SiC-DMOSFETs. Mater. Sci. Forum 2009, 600-603, 1231-1234. [CrossRef]

15. De, D.; Castellazzi, A.; Solomon, A.; Trentin, A.; Minami, M.; Hikihara, T. An all SiC MOSFET high performance PV converter cell. In Proceedings of the 15th European Conference on Power Electronics and Applications (EPE 2013), Lille, France, 2-6 September 2013; pp. 1-10.

16. Nashida, N.; Hinata, Y.; Horio, M.; Yamada, R.; Ikeda, Y. All-SiC power module for photovoltaic power conditioner system. In Proceedings of IEEE 26th International Symposium Power Semiconductor Devices \& IC's (ISPSD 2014), Waikoloa, HI, USA, 15-19 June 2014; pp. 342-345.

17. Burkart, R.M.; Kolar, J.W. Comparative evaluation of SiC and Si PV inverter systems based on power density and efficiency as indicators of initial cost and operating revenue. In Proceedings of IEEE 14th Workshop on Control and Modeling for Power Electronics (COMPEL), Salt Lake City, UT, USA, 23-26 June 2013; pp. 1-6.

18. Sintamarean, C.; Blaabjerg, F.; Wang, H. Comprehensive evaluation on efficiency and thermal loading of associated $\mathrm{Si}$ and $\mathrm{SiC}$ based PV inverter applications. In Proceedings of the 39th Annual Conference IEEE Industrial Electronics Society (IECON 2013), Vienna, Austria, 10-13 November 2013; pp. 555-560.

19. Ho, C.N.-M.; Breuninger, H.; Pettersson, S.; Escobar, G.; Canales, F. A comparative performance study of an interleaved boost converter using commercial Si and SiC diodes for PV Applications. IEEE Trans. Power Electron. 2013, 28, 289-299. [CrossRef]

20. Kim, T.; Jang, M.; Agelidis, V.G. Current status of Silicon Carbide power devices and their application in photovoltaic converters. In Proceedings of IEEE ECCE Asia Downunder (ECCE Asia), Melbourne, Australia, 3-6 June 2013; pp. 555-559.

21. Oku, T.; Matsumoto, T.; Hiramatsu, K.; Yasuda, M.; Shimono, A.; Takeda, Y.; Murozono, M. Construction and characterization of spherical Si solar cells combined with SiC electric power inverter. AIP Conf. Proc. 2015, 1649, 79-83.

22. Matsumoto, T.; Oku, T.; Hiramatsu, K.; Yasuda, M.; Shirahata, Y.; Shimono, A.; Takeda, Y.; Murozono, M. Evaluation of photovoltaic power generation system using spherical silicon solar cells and $\mathrm{SiC}-\mathrm{FET}$ inverter. AIP Conf. Proc. 2016, 1709, 020023. [CrossRef]

23. Oku, T.; Matsumoto, T.; Hiramatsu, K.; Yasuda, M.; Ohishi, Y.; Shimono, A.; Takeda, Y.; Murozono, M. Construction and evaluation of photovoltaic power generation and power storage system using $\mathrm{SiC}$ field-effect transistor inverter. AIP Conf. Proc. 2016, 1709, 020024. [CrossRef]

24. Ando, Y.; Oku, T.; Yasuda, M.; Shirahata, Y.; Ushijima, K.; Murozono, M. A compact SiC photovoltaic inverter with maximum power point tracking function. Solar Energy 2017, 141, 228-235. [CrossRef]

25. Oku, T.; Ando, Y.; Yasuda, M.; Shirahata, Y.; Ushijima, K.; Murozono, M. Construction of photovoltaic power generation-storage system using an inverter with SiC FET and SBD. Adv. Energy Power 2017, 5, 7-12.

26. Oku, T.; Kanayama, M.; Ono, Y.; Akiyama, T.; Kanamori, Y.; Murozono, M. Microstructures, optical and photoelectric conversion properties of spherical silicon solar cells with anti-reflection $\mathrm{SnO}_{\mathrm{x}}: \mathrm{F}$ thin films. Jpn. J. Appl. Phys. 2014, 53, 05FJ03-1-7. [CrossRef] 
27. Texas Instruments. Datasheet of BQ24650-Synchronous Switching-Mode Battery Charge Controller for Solar Power with Maximum Power Point Tracking. 2016. Available online: http://www.ti.com/lit/ds/symlink/ bq24650.pdf (accessed on 21 April 2017).

28. ROHM Semiconductor. Datasheet of SCS210AJ-SiC Schottky Barrier Diode. 2015. Available online: http:/ / rohmfs.rohm.com/en/products/databook/datasheet/discrete/sic/sbd/scs210aj-e.pdf (accessed on 21 April 2017).

29. ROHM Semiconductor. Datasheet of SCT2120AF-N-Channel SiC Power MOSFET. 2015. Available online: http:/ / rohmfs.rohm.com/en/products/databook/datasheet/discrete/sic/mosfet/sct2120af-e.pdf (accessed on 21 April 2017).

30. Ando, Y.; Oku, T.; Yasuda, M.; Shirahata, Y.; Ushijima, K.; Murozono, M. Comparative study of SiC- and Si-based photovoltaic inverters. AIP Conf. Proc. 2017, 1807, 020020. [CrossRef]

31. Ando, Y.; Shirahata, Y.; Oku, T.; Matsumoto, T.; Ohishi, Y.; Yasuda, M.; Shimono, A.; Takeda, Y.; Murozono, M. Comparison between $\mathrm{SiC}$ - and Si-based inverters for photovoltaic power generation systems. J. Power Eng. 2017, 5, 30-40. [CrossRef]

(C) 2017 by the authors. Licensee MDPI, Basel, Switzerland. This article is an open access article distributed under the terms and conditions of the Creative Commons Attribution (CC BY) license (http:/ / creativecommons.org/licenses/by/4.0/). 